\title{
Peningkatan Keterampilan Menyimak Cerita Anak Melalui Media Film Kartun Pada Siswa Kelas IV SDIT AI Anwar
}

\section{Try Emawati}

SDIT Al Anwar

emmatry@gmail.com

\section{Article History}

accepted 01/11/2020

\begin{abstract}
This research attempts to find the effectiveness of using cartoons as medium for student's listening. By using Classroom Action Research with Kemmis and McTaggart style, the performec steps of research are planning, action implementation, and observation, also reflection. The research is conducted in two cycles.

The research results in the student's initial capability test that is completed $50 \%$. Later the action implementation discovers that the student's results in listening to stories is about $66.67 \%$ completed. Then through the post-test, the 2nd cycle of the research shows that the student's results in listening to stories is about $98 \%$ done.

Based on the comparison of those result numbers, it would be expressed that the post-test result in 2nd cycle is experiencing completeness in the study results of students. Using cartoon media in listening to lesson to stories will be able to increase the study result of students of class IV SDIT Al-Anwar.
\end{abstract}

Keywords: Listening Skill, Cartoon Media

\begin{abstract}
Abstrak
Banyak ditemukan siswa kesulitan dalam kegiatan menyimak. Untuk itu dengan penggunaan media film kartun diharapkan adanya peningkatkan hasil belajar menyimak cerita. Jenis penelitian ini yaitu Penelitian Tindakan Kelas (PTK) dengan model Kemmis dan Mc Taggart. Tahapan-tahapan yang dilakukan meliputi perencanaan, pelaksanaan tindakan dan observasi, serta refleksi Penelitian ini dilakukan dalam dua siklus.

Hasil penelitian ini menunjukkan tes kemampuan awal siswa yang tuntas $50 \%$.Selanjutnya di tindakan siklus I bahwa hasil belajar siswa menyimak cerita dongeng dapat diketahui sebanyak $66.67 \%$ dinyatakan tuntas. Kemudian melalui post test siklus II membuktikan bahwa hasil belajar siswa menyimak cerita dongeng sebanyak $92 \%$ dinyatakan tuntas. Berdasarkan perbandingan jumlah tersebut maka dapat dikemukakan bahwa perolehan hasil post test siklus II mengalami ketuntasan pada hasil belajar siswa. Hal ini membuktikan bahwa tidak perlu dilakukan tindakan perbaikan melalui pelaksanan siklus berikutnya.

Media film kartun pada pembelajaran menyimak cerita dongeng dapat meningkatkan hasil belajar siswa kelas IV SDIT AI Anwar.
\end{abstract}

Kata kunci: Keterampilan Menyimak, Media Film Kartun

Social, Humanities, and Education Studies (SHEs): Conference Series https://jurnal.uns.ac.id/shes

p-ISSN 2620-9284

e-ISSN 2620-9292 
A. Latar Belakang Masalah

\section{PENDAHULUAN}

Keterampilan dasar yang perlu siswa miliki salah satunya adalah keterampilan menyimak. Menyimak merupakan proses menangkap pesan atau gagasan yang disajikan melalui bahasa lisan. Keterampilan menyimak menjadi dasar bagi beberapa keterampilan berbahasa lain karena menyimak merupakan keterampilan berbahasa yang sangat penting, di samping membaca, berbicara, dan menulis (Ema Febru Aries, 2011)

Logan et all (dalarn Kundharu Saddhono \& St. Y. Slarnet, 2012: 18-19) rnengklasifikasikan rnenyirnak atas dasar tujuan khusus, yaitu Menyirnak untuk belajar, menghibur, menilai, apresiatif, mengkomunikasikan ide dan perasaan, deskriminatif, pemecahan masalah. Berdasarkan pendapat di atas keterampilan menyimak cerita merupakan jenis keterampilan menyimak intensif, menyimak untuk belajar dan menyimak apresiatif.

Salah satu materi simakan di sekolah dasar adalah cerita anak dengan kompetensi dasar menilai pendapat pribadi tentang isi buku sastra (cerita, dongeng, dan sebagainya). Sukimo (2010: 85-91) mengungkapkan bahwa unsur-unsur pembangun cerita adalah sebagai berikut: (a) Pelaku Alur, (b) Latar, (c) Sudut Pandang, (d) Terna, (e) Amanat, (f) Kata-kata transisi.

dengan menegaskan unsur-unsur cerita seperti tema, latar, tokoh dan pesan yang terdapat di dalam cerita anak. Kenyataan di lapangan banyak siswa kesulitan dalam kegiatan menyimak. Hal tersebut terlihat dengan hasil belajar menyimak cerita anak siswa kelas IV SDIT AI Anwar masih rendah, banyak yang belum mencapai nilai ketuntasan minimal (KKM). Nilai rata-rata keterampilan menyimak cerita pendek siswa hanya 65 dilihat dari hasil evaluasi. Nilai tersebut lebih kecil dari nilai KKM mata pelajaran Bahasa Indonesia yaitu 75. Rendahnya kemampuan menyimak cerita siswa selain dilihat dari hasil belajar juga disebabkan oleh beberapa faktor antara lain guru belum menggunakan media pembelajaran yang dapat menarik perhatian siswa karena kurangnya sarana dan prasarana yang mendukung dalam proses pembelajaran. Sebagian besar siswa masih kesulitan dalam memahami isi dari cerita karena siswa kurang memperhatikan penjelasan guru terkait materi cerita yang disampaikan, akibatnya hasil belajar siswa dalam keterampilan menyimak rendah.

Masalah tersebut dapat diatasi dengan pembelajaran menyimak yang benar dan latihan secara rutin karena suatu keterampilan dapat diperoleh dan dikuasai dengan jalan praktik dan banyak latihan. Selain itu, untuk meningkatkan keterampilan menyimak siswa dalam proses pembelajaran, seorang guru hendaknya mampu menciptakan suasana pembelajaran yang menyenangkan dan mampu menarik minat belajar siswa serta dapat melibatkan siswa secara aktif dalam mengikuti proses pembelajaran sehingga siswa lebih mudah memahami isi cerita. Salah satu cara untuk menciptakan suasana pembelajaran yang menyenangkan yaitu guru harus menggunakan metode yang tepat, strategi maupun media pembelajaran yang variatif, efektif dan efisien serta mampu menerapkan pengajaran berdasarkan pengalaman belajar siswa. Dalam proses belajar mengajar, metode, strategi maupun media pembelajaran memiliki peran yang sangat penting untuk menunjang tujuan pembelajaran yang efektif dan efisien guna tercapainya pembelajaran yang optimal.

Salah satu upaya yang dapat dilakukan untuk meningkatkan keterampilan menyimak siswa yaitu adanya penggunaan media dalam proses pembelajaran. Dalam proses pembelajaran, seorang guru harus 
dapat memilih media yang tepat sesuai dengan materi yang akan diajarkan. Ali Mustadi (2010) menjelaskan bahwa media pembelajaran merupakan alat untuk membantu dalam menyesuaikan tujuan pembelajaran dengan produk pembelajaran. Penggunaan media dalam pembelajaran menyimak sebagai salah satu altematif untuk membuat proses pembelajaran lebih menarik dan menyenangkan. Proses pembelajaran yang menarik dan menyenangkan mampu menumbuhkan motivasi siswa untuk belajar dan mengaktifkan siswa untuk giat lagi dalam belajar.

Beberapa media pembelajaran yang dapat dipilih dan digunakan oleh guru dalam kegiatan pembelajaran antara lain: media audifit, media visual dan media audiovisual. Melalui media-media pembelajaran inilah guru dapat menciptakan kondisi pembelajaran yang menyenangkan bagi siswa. Berdasarkan hal tersebut diharapkan siswa dapat memperoleh hasil belajar yang optimal.

Media audiovisual adalah jenis media yang mempunyai unsur suara dan unsur gambar (Syaiful Bahri Djamarah dan Aswan Zain, 2010). Media audiovisual yang digunakan dalam penelitian ini yaitu berupa film kartun. Media film kartun dipilih karena jenis media ini mempunyai kemampuan yang lebih baik, yaitu mengandung unsur suara dan gambar. Selain itu, pemilihan penggunaan film kartun ini dimaksudkan sebagai media siswa memahami hal-hal yang abstrak melalui hal-hal yang konkret. Sesuai dengan tingkat perkembangan kognitif anak SD yang masih dalam tahap operasional konkret, dengan penggunaan media film kartun, siswa mampu menerima unsur-unsur cerita yang nyata melalui cerita yang ditayangkan.

Berdasarkan paparan di atas, dengan adanya media film kartun yang digunakan sebagai media pembelajaran diharapkan dapat meningkatkan keterampilan menyimak siswa dalam memahami isi cerita pendek sehingga siswa dapat memperoleh hasil yang optimal melalui bahan simakan. Dengan demikian, keterampilan menyimak cerita pendek siswa kelas IV SDIT Al Anwar Mayong melalui penggunaan media film kartun dapat meningkat.

\section{B. Identifikasi Masalah}

Berdasarkan latar belakang masalah yang telah dikemukakan di atas, dapat diidentifikassikan beberapa masalah dibawah ini:

a. Kurangnya media pembelajaran untuk pengajaran keterampilan menyimak cerita.

b. Kurangnya perhatian siswa dalam menyimak suatu cerita.

c. Rendahnya kemampuan siswa dalam menemukan tokoh, tema, latar dan amanat dalam sebuah cerita.

d. Belum digunakan media film kartun dalam pembelajaran menyimak cerita.

\section{Analisis Masalah}

Dari identifikasi masalah maka muncul analisis masalah sebagai berikut:

a. Guru menggunakan media yang kurang tepat dalam pembelajaran menyimak dongeng.

b. Hasil belajar pada materi menyimak siswa masih kurang

\section{Rumusan Masalah}

Berdasarkan latar belakang di atas, maka rumusan masalah tersebut sebagai berikut:

a) bagaimanakah penggunaan media fim kartun untuk meningkatkan keterampilan menyimak cerita siswa kelas IV SDIT AI Anwar? 
b) bagaimanakah hasil belajar menyimak cerita siswa kelas IV SDIT AI Anwar dengan penggunaan media film kartun?

\section{E. Tujuan Penelitian}

Berdasarkan rumusan masalah tersebut, maka tujuan penelitian tersebut adalah agar pembaca mampu:

a) mendeskripsikan penggunaan media film kartun untuk meningkatkan keterampilan menyimak cerita siswa kelas IV SDIT AI Anwar.

b) meningkatkan hasil belajar menyimak cerita siswa kelas IV SDIT AI Anwar dengan penggunaan media film kartun.

F. Manfaat Penelitian

Hasil penelitian ini diharapkan dapat memberikan manfaat teoristis dan praktis.

\section{Manfaat Teoritis}

Manfaat teoritis antara lain hasil penelitian dapat dipergunakan sebagai informasi atau dasar perbaikan kualitas pembelajaran di sekolah dasar.

\section{Manfaat Praktis}

Adapun manfaat praktis dari hasil penelitian ini adalah sebagai berikut :

a. Siswa

Siswa dapat lebih memahami materi menyimak cerita.

b. Guru

Hasil penelitian ini dapat dipergunakan untuk menambah strategi baru yang tepat dalam mendukung pembelajaran.

c. Sekolah

Hasil penelitian ini dapat digunakan sebagai masukan positif terhadap kemajuan sekolah

d. Perpustakaan sekolah

Hasil penelitian dapat dipergunakan sebagai acuan atau sebagai referensi dalam pembelajaran.

\section{METODE}

Suharsimi Arikunto, dkk (2012) mengemukakan bahwa penelitian tindakan kelas adalah penelitian tindakan yang dilakukan di kelas dengan tujuan memperbaiki atau meningkatkan mutu praktik pembelajaran. PTK ini dilaksanakan dua siklus. Pelaksanaannya meliputi tiga langkah, yaitu: Planning-Perencanaan, Acting \& Observing, dan Reflecting-Refleksi. Penelitian ini dilaksanakan di SDIT Al Anwar Jl. Pesantren Gleget Mayonglor Mayong Jepara. Subjek penelitian adalah guru dan siswa kelas IV dengan jumlah 24 siswa yang terdiri dari 12 siswa laki-laki dan 12 siswa perempuan. Pemilihan subjek ini karena dijumpai permasalahan sebelumnya, yaitu guru tidak menggunakan media pembelajaran dan keterampilan menyimak cerita siswa kelas IV masih rendah. Hal ini didukung dengan hasil belajar yang menunjukkan bahwa $50 \%$ atau 12 orang dari 24 siswa, nilainya di bawah KKM muatan pelajaran Bahasa Indonesia yang ditetapkan oleh sekolah yaitu 75 .

Teknik pengumpulan data dalam penelitian ini adalah observasi, tes, dan catatan lapangan. Observasi dipergunakan untuk mengumpulkan data tentang aktivitas guru selama kegiatan berlangsung. Pengamatan dilakukan oleh dua orang observer yaitu guru kelas IV dan teman sejawat. Tes diberikan di akhir pembelajaran pada masing-masing siklus untuk mengetahui hasil belajar siswa. Catatan lapangan digunakan untuk mengetahui kendala-kendala yang dihadapi dalam pembelajaran. Dari hasil catatan diperoleh data berbagai kendala yang dihadapi selama proses pembelajaran menggunakan media film kartun untuk selanjutnya diupayakan cara mengatasi kendala-kendala tersebut. 


\section{HASIL DAN PEMBAHASAN.}

\section{Penyajian Data Siklus I}

\section{a. Tahap Perencanaan}

Pada tahap ini peneliti membuat alternative pemecahan (Rencana Tindakan) dalam mengatasi kesulitan siswa yaitu:

1. Melakukan analisis permasalahan yang akan di pecahkan dalam penelitian ini.

2. Menyusun Rencana Pelaksanaan Pembelajaran (RPP) yang berisikan langkah-langkah kegiatan dalam pembelajaran.

3. Menyiapkan materi yang akan di bahas.

4. Menyiapkan soal test akhir pada siklus I dan indikator keberhasilan pencapaian hasil belajar.

5. Menyususn alat evaluasi (test) untuk mengetahui hasil belajar siswa

6. Menyiapkan dokumentasi

\section{c. Tahap Pelaksanaan}

Pada tahap ini penelitian ini melaksanakan kegiatan penelitian yang sudah direncanakan pada tahap sebelumnya

1. Menyiapkan tujuan pokok pembelajaran

2. Melaksanakan penelitian dengan melakukan pembelajaran dengan membacakan cerita, tanya jawab, diskusi, dengan cara memberikan pengorganisasian tugas sesuai dengan RPP.

\section{d. Tahap Pengamatan/ Observasi}

Kegiatan yang dilakukan pada tahap ini adalah melakukan pengamatan yang dilakukan sekaligus ketika tahap pelaksanaan berlangsung, dengan tujuan melihat apakah kondisi belajar siswa dengan dibacakan cerita oleh guru telah sesuai atau tidak dengan perancanaan pembelajaran yang ditetapkan.Untuk mengetahui hasil observasi terhadap aktiviyas guru dan siswa selama pelaksanaan pembelajaran pada siklus I dapat dikemukan dengan tabel berikut.

Petunjuk : Beri tanda angka pada kolom sesuai dengan pengamatan
1. Kurang
3. Baik
2. Sedang
4. Sangat Baik

Tabel 4.3

\section{Lembar Observasi Aktivitas Siswa}

Siklus I

\begin{tabular}{|c|c|c|c|c|c|c|}
\hline \multirow[t]{2}{*}{ No } & \multirow[t]{2}{*}{ Aspek yang diamati } & \multicolumn{4}{|c|}{ skor } & \multirow{2}{*}{$\begin{array}{l}\text { Juml } \\
\text { ah }\end{array}$} \\
\hline & & 1 & 2 & 3 & 4 & \\
\hline 1. & Siswa aktif dalam pembelajaran & & & 3 & & 3 \\
\hline 2. & $\begin{array}{l}\text { Siswa berani bertanya dan menjawab } \\
\text { pertanyaan yang diberikan oleh guru }\end{array}$ & & & 3 & & 3 \\
\hline
\end{tabular}




\begin{tabular}{llc}
\hline 3. $\begin{array}{l}\text { Siswa berinteraksi dan bekerja sama dengan siswa } \\
\text { lain }\end{array}$ & 3 & 3 \\
4. $\begin{array}{l}\text { Siswa dapat mengikuti materi pelajaran dengan } \\
\text { baik }\end{array}$ & 4 & 4 \\
5. $\begin{array}{l}\text { Siswa dapat memahami materi pelajaran yang } \\
\text { berlangsung }\end{array}$ & 3 & 3 \\
6. $\begin{array}{l}\text { Siswa memahami tujuan pembelajaran dengan } \\
\text { menggunakan media dan alat praga } \\
\text { Jumlah } \\
\text { Rata-rata }\end{array}$ & 4 & 4 \\
$\quad$ & 2 \\
\hline
\end{tabular}

Berdasarkan hasil observasi siklus I secara keseluruhan aktivitas siswa kurang memuaskan dengan hasil perhitungan rata-rata 3,33.

\section{e. Tahap Refleksi}

Hasil refleksi ini sebagai rujukan untuk melaksanakan perbaikanperbaikan pada pelaksanaan pembelajaran selanjutnya siklus I.

Tabel 4.4

Hasil belajar siswa saat Post Test Siklus I

\begin{tabular}{|c|c|c|c|c|}
\hline No & $\begin{array}{l}\text { Nama } \\
\text { Siswa }\end{array}$ & $\begin{array}{l}\text { Jumlah } \\
\text { Skor }\end{array}$ & Nilai & Keterangan \\
\hline 1 & ADITYA ILHAM MAULANA & 8 & 80 & TUNTAS \\
\hline 2 & $\begin{array}{l}\text { ALDO GALIH VIRGIAN } \\
\text { PRATAMA }\end{array}$ & 5 & 50 & TIDAK TUNTAS \\
\hline 3 & ALMIRA ALCHALAFI JUNAIDI & 8 & 80 & TUNTAS \\
\hline 4 & ALYA RIDHA LESTARI & 8 & 80 & TUNTAS \\
\hline 5 & AZKA AULIA PUTRI & 7 & 70 & TIDAK TUNTAS \\
\hline 6 & CANDRA ADITIA & 7 & 70 & TIDAK TUNTAS \\
\hline 7 & DAMMAS ADITYA PRATAMA & 8 & 80 & TUNTAS \\
\hline 8 & DEVI NOVITASARI & 7 & 70 & TIDAK TUNTAS \\
\hline 9 & FAIZ SOFWAN ARRAFI & 8 & 80 & TUNTAS \\
\hline 10 & FANNY CHASANI & 9 & 90 & TUNTAS \\
\hline 11 & FITROTUN NASIKHAH & 8 & 80 & TUNTAS \\
\hline 12 & IZZATUR RUHANIYYAH & 9 & 90 & TUNTAS \\
\hline 13 & KHOIRUZ ZADIT TAQWA & 8 & 80 & TUNTAS \\
\hline 14 & M. KHAIKAL RAMADHANI & 9 & 90 & TUNTAS \\
\hline 15 & MIFTAKHUL JANNAH & 7 & 70 & TIDAK TUNTAS \\
\hline 16 & MILLA EVIA RISTA & 8 & 80 & TUNTAS \\
\hline 17 & MUHAMMAD AQILLA FAHLEVI & 7 & 70 & TIDAK TUNTAS \\
\hline 18 & MUHAMMAD FAJRUL FALAH & 8 & 80 & TUNTAS \\
\hline
\end{tabular}




\begin{tabular}{llllc}
\hline 19 & MUHAMMAD NAUFAL ADZ- & 8 & 80 & TUNTAS \\
20 & M̄ÜHÄM̄MMADAD RAIHAN AL JADID & 9 & 90 & TUNTAS \\
21 & MYANKA AURA CAHYANI & 7 & 70 & TIDAK TUNTAS \\
22 & NUR AHMAD ATHIF FADHLI & 9 & 90 & TUNTAS \\
23 & PUTRI SARAH AULIA & 6 & 70 & TIDAK TUNTAS \\
24 & QUEEN BELVA AMALIA NAJIB & 8 & 80 & TUNTAS \\
\hline
\end{tabular}

Untuk mengetahui ketuntasan belajar siswa dari hasil Post Test siklus I dapat digambarkan dalam bentuk grafik sebagai berikut:

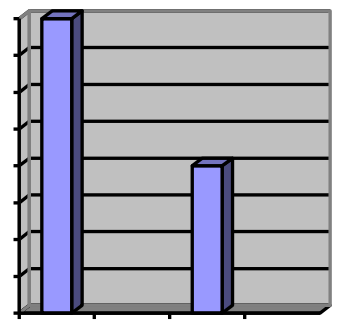

\section{Gambar 4.2 \\ Hasil Belajar Siswa Pada Post Test (Siklusl)}

Berdasarkan hasil evaluasi bahwa hasil belajar siswa pada menyimak cerita, dapat diketahui sebanyak 16 siswa (66.67\%) dinyatakan tuntas dan sebanyak 8 siswa (33.33\%) dinyatakan tidak tuntas. Dengan demikian dapat disimpulkan bahwa pada siklus I siswa tidak mencapai ketuntasan belajar sehingga perlu dilakukan tindakan perbaikan melalui pelaksanaan siklus I

Berdasarkan hasil evaluasi bahwa hasil belajar siswa pada menyimak cerita, dapat diketahui sebanyak 16 siswa $(66.67 \%)$ dinyatakan tuntas dan sebanyak 8 siswa (33.33\%) dinyatakan tidak tuntas. Dengan demikian dapat disimpulkan bahwa pada siklus I siswa tidak mencapai ketuntasan belajar sehingga perlu dilakukan tindakan perbaikan melalui pelaksanaan siklus I

\section{Tindakan II}

Berdasarkan tabel deskripsi hasil siklus I dapat dilihat dari hasil belajar siswa pada pembejaran menyimak cerita mulai meningkat. Akan tetapi belum mencapai $\mathrm{KKM}$, maka dalam hal ini dilaksanakan siklus berikutnya. 




$\square \quad$ JUMLAH SISWA

\section{Gambar 4.3}

\section{Hasil Belajar Siswa Pada Post Test (Siklus II)}

Berdasarkan hasil belajar siswa siklus II dapat dilihat bahwa analisis hasil belajar menyimak cerita lebih baik dibandingkan dengan siklus I. Peningkatan ketuntasan belajar siswa pada siklus II cukup baik. Pada siklus I (pre test) dengan nilai rata-rata 53 dan presentase ketuntasannya yaitu $20 \%$, pada siklus I (post test) dengan nilai rata-rata 78 dan presentase ketuntasannya yaitu $66.67 \%$, pada siklus II (post test) dengan nilai rata-rata 87 dan presentase ketuntasanny yaitu 92\%. Oleh karena itu tidak perlu ada perbaikan lanjut, sebab telah terjadi peningkatan ketuntasan pada hasil belajar di siklus II.

Tabel 4.8

Data Penelitian Hasil Belajar Menyimak Cerita IV SDIT AI Anwar (Pre Test, Post Test Siklus I, Post Test Siklus II)

\begin{tabular}{|c|c|c|c|c|c|}
\hline NO & \multicolumn{2}{|c|}{ HASIL TES } & PRESENTASE & RATA-RATA & KETERANGAN \\
\hline 1 & Pre test & $\begin{array}{c}\text { Tuntas } \\
\text { Tidak Tuntas }\end{array}$ & $\begin{array}{l}50 \% \\
50 \%\end{array}$ & 72 & Tidak Tuntas \\
\hline 2 & Post test siklus 1 & $\begin{array}{c}\text { Tuntas } \\
\text { Tidak Tuntas }\end{array}$ & $\begin{array}{l}66,67 \% \\
33,33 \%\end{array}$ & 78 & Tidak Tuntas \\
\hline 3 & Post test siklus 2 & $\begin{array}{c}\text { Tuntas } \\
\text { Tidak Tuntas }\end{array}$ & $\begin{array}{c}92 \% \\
8 \%\end{array}$ & 87 & Tuntas \\
\hline
\end{tabular}

\section{Penelitian yang Relevan}

a. Penelitian yang relevan dengan penelitian ini adalah penelitaian yang dilakukan oleh Wahdatin Rusdiana dengan judul "Meningkatkan Keterampilan Menyimak Dongeng Menggunakan Media VCD Film Kartun Pada Siswa Kelas II SD Negeri 2 Wates, Kulon Progo, Yogyakarta". Hasil data sebelum diadakan tindakan rata-rata keterampilan menyimak siswa yaitu 66,79. Setelah diberikan tindakan rata-rata keterampilan menyimak siswa menjadi 75,29 atau meningkat 8,5. Sementara pada siklus II rata-rata keterampilan menyimak siswa meningkat menjadi 84,06 atau meningkat 8, 77. Sehingga peningkatan keterampilan menyimak dari siklus I sampai siklus II meningkat $28,94 \%$.

b. Penelitian yang relevan dengan penelitian ini adalah penelitaian yang dilakukan oleh Sigit Purw anto dengan judul "Peningkatan Keterampilan Menyimak Dongeng Menggunakan Media VCD Pada Siswa Kelas V SD Negeri 1 Sudorogo Purworejo". Hasil nilai rata-rata keterampilan menyimak dongeng pada siklus I sebesar 10,58 yaitu, nilai rerata awal sebesar 54 meningkat menjadi 64,58 dan pada siklus 2 
meningkat menjadi 11,67 yaitu, dari nilai rerata siklus I 64,58 meningkat menjadi 76,25. Sehingga peningkatan keterampilan menyimak dari siklus I sampai siklus II meningkat 22,25.

\section{SIMPULAN}

Berdasarkan hasil siklus I dan siklus II, dengan menggunakan media film kartun untuk meningkatkat kemampuan menyimak muatan pelajaran Bahasa Indonesia di kelas IV SDIT Al Anwar tahun 2020 dapat disimpulkan beberapa hal sebagai berikut sebelum menggunakan media film kartun untuk menyimak cerita mengikuti pre test yang diperoleh rata-rata 72 dengan presentase $50 \%$ tuntas atau dengan kata lain tidak mencapai KKM 75.

Setelah menggunakan media film kartun untuk menyimak cerita dongeng terjadi peningkatan disetiap siklusnya. setelah dilakukannya tindakan didapatkan hasil belajar siswa pada post tes (Siklus I) yakni sebesar $66.67 \%$, rata-rata 78 dengan jumlah siswa yang tuntas mencapai 16 orang atau telah melewati nilai KKM 75 , sedangkan siswa yang tidak tuntas mencapai 33,33\% dengan jumlah siswa 8 orang yang tidak mencapai nilai KKM 75. Kemudian pada siklus II mengalami peningkatan,terdapat 22 siswa mencapai nilai 80 ke atas dengan presentase $92 \%$ dan nilai rata-rata 87.

Dapat di lihat dari pembelajaran sebelum dan sesudah dilakukan media film kartun untuk menyimak cerita dongeng, hasil belajar siswa mengalami peningkatan. Dengan demikian dapat disimpulkan bahwa dengan media film kartun dalam pembelajaran dapat meningkatkan hasil belajar siswa pada menyimak cerita dongeng dikelas IV di SDIT AI Anwar Mayong.

\section{DAFTAR PUSTAKA}

Ali Mustadi. (2010). Peningkatan Prestasi Belajar Mahasiswa melalui Metode Task Based Teaching (Tbt) Pada Mata Kuliah Bahasa Inggris di PGSD, FIP, UNY. Jurnal Majalah Ilmiah PGSD, Vol. 1 No. 1, Hlm 48.

Ema Febru Aries. (2011). Asesmen dan Evaluasi. Malang: Aditya Media Publishing.

Kundharu Saddhono \& St. Y. Slamet. (2012). Meningkatkan Keterampilan Berbahasa Indonesia (Teori dan Aplikasi). Jakarta: CV Karya Putra.

Sigit Purwanto. (2013). Peningkatan Keterampilan Menyimak Dongeng dengan Menggunakan Media VCD pada Siswa Kelas V SD Negeri 1 Sudorogo Purworejo. Skripsi. Yogyakarta.

Suharsimi Arikunto, Suhardjono, \& Supardi. (2012). Penelitian Tindakan Kelas. Jakarta: PT Bumi Aksara.

Sukimo. (2010). Belajar Cepat Menulis Kreatif Berbasis Kuantum. Yogyakarta: Pustaka Pelajar.

Syaiful Bahri Djamarah dan Aswan Zain. (2010). Strategi Belajar Mengajar. Jakarta: Rineka Cipta.

Wahdatin Rusdiana. (2013). Peningkatan Keterampilan Menyimak Dongeng dengan Menggunakan Media VCD Film Kartun pada Siswa Kelas II SD Negeri 2 Wates, Kulon Progo. Skripsi. Yogyakarta. 